\title{
The Use of Quality Tools to Reduce Surface Defects of Painted Steel Structures
}

Krzysztof Knop (0000-0003-0842-9584)

Faculty of Management, Czestochowa University of Technology. Armii Krajowej 19B, 42-200 Czestochowa. Poland. E-mail: krzysztof.knop@wz.pcz.pl

The article presents the results of the use of quality instruments - tools and techniques - in order to reduce surface defects of steel structures on the example of a selected element - engine cover of asphalt milling machines. The article shows the potential of using selected quality tools - basic and new - in the service of quality analysis and improvement. Quantitative analyzes were presented out using the ParetoLorenz diagram and the c control chart, qualitative analyzes using the Ishikawa diagram and the FMEA method, quantitative \& qualitative analyzes using the interrelationship diagram and matrix diagram, and it was proposed quality improvement using qualitative tools such as affinity diagram, and PDPC diagram. The most common defects of painted surfaces turned out to be improper thickness and surface contamination. As it has been shown, the experience of employees is largely responsible for the cause of these defects, which was also confirmed by other analyses carried out with the use of quality tools. The training was the most frequent method of prevention. It has also been shown that special attention should be paid to quality control, its effectiveness, and quantity. The article proves that correctly used quality tools can contribute to the improvement of the quality of manufactured products, helps in solving various quality problems.

Keywords: quality management, quality tools, steel structures, improvement

\section{Introduction}

Quality is compliance with requirements. A nonconformity is any failure to meet a requirement, in turn, a defect is a nonconformance, damage that reduces the value of the product, does not allow the full value of the intended use or failure to meet the requirements of the product to a degree that prevents its use [1]. The line between a defect and nonconformity is that every defect is a nonconformity, but not all nonconformities are defects [2]. Each nonconformity or defect is associated with costs, such as the need for rework or repair if it is economically justified or complaints from customers if such a product reaches the customer [3]. In order to analyze and reduce the number of nonconformities and defects, quality instruments so quality tools and techniques are very often used [4]. Quality tools have a clear function and are applied by themselves, while quality techniques are a set of tools and have a broader application (e.g., statistical process control that uses histograms, process diagrams, and control charts); a quality technique has a wider application than a tool $[5,6]$. Generally, quality tools are used to collect and process data and information, as well as to detect errors, defects, and irregularities in processes, products, or services [7-9]. Quality tools are for summarizing data and organizing its presentation, data-collection and structuring ideas, identifying relationships, discovering and understanding a problem, implementing the action, finding and removing the causes of the problem, selecting problems for improvement and assisting with the setting of priorities, planning, and performance measurement and capability assessment [10]. Quality tools' key roles are for quality management and continuous improvement $[11,12]$, but there is no one tool or technique which is more important than others in the quality improvement process $[6,13] .95 \%$ of quality-related problems can be resolved with quality tools [14]. Quality tools can be used in all phases of the production process, from the beginning of product development up to product marketing and customer support. Their applications for quality improvement are found in almost all manufacturing and service organizations, with different sizes, and in everyday situations [5, 15-17]. Quality tools consist of the seven basic and seven new (called also seven management and planning tools or simply the seven management tools) [18]. Basic quality tools are based primarily on numerical data; they are used to aid in data collection and consolidation, problem definition and/or resolution, pattern or trend analysis, and process analysis [14]. They are suitable for people with little formal training in statistics and they can be used to solve the vast majority of qualityrelated issues [6]. The seven basic tools are the Ishikawa diagram, check sheet, control chart, histogram, Pareto chart, scatter diagram, and stratification (alternatively, flow chart or run chart) [3,19]. The new quality tools complement the basic quality tools [20]; they are based primarily on verbal (descriptive) data 
and require teamwork when using them [21]. The new quality tools are affinity diagram, interrelationship diagram, tree diagram, matrix diagram, matrix data analysis, arrow diagram, process decision program chart $[21,22]$. The new seven tools allow for more identification, planning, and coordination in finding a problem solution [23]. They are used together with the basic quality tools to increase the Total Quality Management (TQM) effectiveness [10, 14]. The role of the quality tools is obvious in the increase in customer demand looking for better product quality [24]. There are some critical success factors that require attention in order to make the use of quality tools effective and efficient to improve the organization's performance, such as full management support and commitment; effective, timely, and planned training; a genuine need to use the tool or technique; defined aims and objective for use; a cooperative environment; and backup and support from improvement facilitators [13].

The article presents the potential of selected basic and new quality tools and one quality technique for the analysis and improvement of the quality of steel structures.

\section{Research methodology}

The aim of the research is to analyze the surface defects of painted steel structures on the example of a selected element manufactured by the company - engine covers of asphalt milling machines, with the use of selected basic and new quality tools, also with the use of one quality technique. The research was to show the potential of selected quality instruments in the analysis, evaluation, and improvement of the quality level of the tested product. This article aims to analyze the number of occurrences, the causes of surface defects of painted steel structures on the example of a selected element produced by the examined company, and to propose actions that will contribute to reducing the probability of these defects.

The object of the research is a company whose main assortment is welded structures, parts for road and metallurgical machines as well as steel and aluminum compressor components. Currently, the company's assortment includes the following products and services: thermal deburring, welding, steel and special structures, pressure vessels, transport services, powder coating, wet painting. All offered products are made for the customer's special order. In order to meet high customer requirements and meet international standards, the surveyed company is constantly developing, and the received management system certificates confirm its qualifications.

The analyzed product in the company is the engine cover of asphalt milling machines, whose purpose is to isolate the engine from the environment.

The article presents analyzes aimed at presenting important factors influencing the formation of defects in painted surfaces, their interdependence, and the specification of the most significant ones and in effects the proposals of quality improvement. Based on the collected relevant data, quantitative analyzes will be carried out (Pareto-Lorenz chart and c control chart), then qualitative (Ishikawa diagram, FMEA analysis) and quantitative-qualitative (interrelationship diagram, matrix diagram), which will be resulting in the quality improvement proposals presented by another set of quality tools (affinity diagram, PDPC diagram). A total of eight quality tools and techniques will be used: three basic quality tools, known as quality control tools (Pareto-Lorenz diagram, c control chart, Ishikawa diagram), one quality technique (FMEA analysis), and four new quality tools, known as quality management tools (interrelationship diagram, matrix diagram affinity diagram, and PDPC diagram). Table 1 provides a brief overview of each of the quality techniques and tools used, as well as the classification of these quality instruments [25].

The basic quality tools have been used because they are especially suitable for detecting "places" in processes where defects and non-conformities arise and then investigating their causes. They will be used to detect defects in steel structures and to analyze them. New quality tools were used in the analyzes because they help in finding relationships between data and ideas and grouping them according to specific criteria. They will also be used to describe the sequence and characteristics of actions leading to a specific goal - solving the problem, i.e. defects in painted structures. The implementation of such quality instruments in the organization was aimed at improving the quality and efficiency of the steel structure manufacturing process, minimizing quality costs and the risk of defects [33], and, as a result, ensuring end-customer satisfaction $[34,35]$.

The selection of quality tools for the research was also dictated by their knowledge by the members of the working group from the examined enterprise and the relative ease and speed of quality tools usage (compared to more advanced quality techniques) [12]. Quality tools are generally easy to use and universal - they can be used to analyze various data and problems from various industries $[4,7,9,14]$. The results of their application are also visible "almost" immediately. In such a set and configuration ( 3 basic, 4 new, 1 technique), they were used for the first time in the company to reduce the possibility of defects occurring in painted steel structures.

The article will allow learning about the most common defects of steel structures along with the characteristics of their formation and causes, which will allow for better prevention of their occurrence in the future. The article aims to expand the knowledge in 
the field of analysis of defects in painting steel structures with the use of quality tools and techniques in the aim to increase the quality level of produced steel structures.

Tab. 1 Overview of used in the analysis quality tools and technique and their classification

\begin{tabular}{|c|c|c|c|}
\hline Tool & $\begin{array}{l}\text { Tool classifi- } \\
\text { cation }\end{array}$ & $\begin{array}{l}\text { Type of } \\
\text { tool }\end{array}$ & Description \\
\hline $\begin{array}{l}\text { Pareto-Lorenz } \\
\text { diagram }\end{array}$ & Tool/7QC & Quantitative & $\begin{array}{l}\text { A bar chart that organizes the data from largest to smallest } \\
\text { to direct attention on the important items. It visually } \\
\text { highlights which situations/problems are more significant } \\
\text { [26]. }\end{array}$ \\
\hline$C$ control chart & Tool/7QC & Quantitative & $\begin{array}{l}\text { Control chart is a graph of time-ordered data that show } \\
\text { how a process changes over time and to identify if a pro- } \\
\text { cess is statistical control or not. It also predicts how a pro- } \\
\text { cess should behave in the future [27-29]. C charts are used } \\
\text { to look at variation in counting type attributes data. They } \\
\text { are used to determine the variation in the number of de- } \\
\text { fects in a constant subgroup size [30]. }\end{array}$ \\
\hline $\begin{array}{l}\text { Ishikawa } \\
\text { diagram }\end{array}$ & Tool/7QC & Qualitative & $\begin{array}{l}\text { A schematic tool that lists causes as they relate to a con- } \\
\text { cern - also Fishbone diagram, Cause and effect diagram } \\
\text { [26] }\end{array}$ \\
\hline FMEA analysis & Technique & Qualitative & $\begin{array}{l}\text { Failure mode and effects analysis. This method is aimed at } \\
\text { preventing the effects of defects that may occur in the de- } \\
\text { sign phase and in the production phase }[31,32] \text {. }\end{array}$ \\
\hline $\begin{array}{l}\text { Interrelationship } \\
\text { diagram }\end{array}$ & Tool/7QM & $\begin{array}{l}\text { Quantita- } \\
\text { tive-qualita- } \\
\quad \text { tive }\end{array}$ & $\begin{array}{l}\text { It shows cause-and-effect relationships. It helps a group } \\
\text { analyze the natural links between different aspects of a } \\
\text { complex situation [20-23]. }\end{array}$ \\
\hline $\begin{array}{c}\text { L-shaped matrix } \\
\text { diagram }\end{array}$ & Tool/7QM & $\begin{array}{l}\text { Quantita- } \\
\text { tive-qualita- } \\
\quad \text { tive }\end{array}$ & $\begin{array}{l}\text { It shows the relationship between two groups of informa- } \\
\text { tion. It also can give information about the strength of the } \\
\text { relationship [20-23]. }\end{array}$ \\
\hline Affinity diagram & Tool/7QM & Qualitative & $\begin{array}{l}\text { It organizes a large number of ideas into their natural rela- } \\
\text { tionships. It is often used to group ideas generated by Bra- } \\
\text { instorming [20-23]. }\end{array}$ \\
\hline $\begin{array}{l}\text { Process decision } \\
\text { program chart } \\
\text { (PDPC) diagram }\end{array}$ & Tool/7QM & Qualitative & $\begin{array}{l}\text { It systematically identifies what might go wrong in a plan } \\
\text { under development. Countermeasures are developed to } \\
\text { prevent or offset those problems [20-23]. }\end{array}$ \\
\hline
\end{tabular}

Legend: 7QC - 7 quality control, 7QM - 7 quality management.

The procedure of using selected quality instruments for quality improvement was presented in Fig. 1. In the first four steps, basic quality tools (two numerical, one descriptive) will be used, and one qualitative technique. This part of the analysis ends with the presentation of the importance (criticality) of defects in steel structures due to the RPN coefficient and the FMEA method. In steps 5 to 8, new quality tools will be applied. The procedure ends with a proposition of remedial actions for the identified causes of quality defects using the PDPC diagram. 


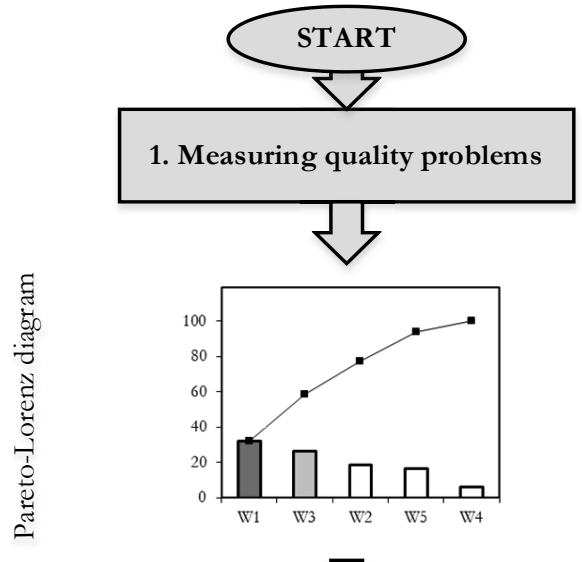

ए?
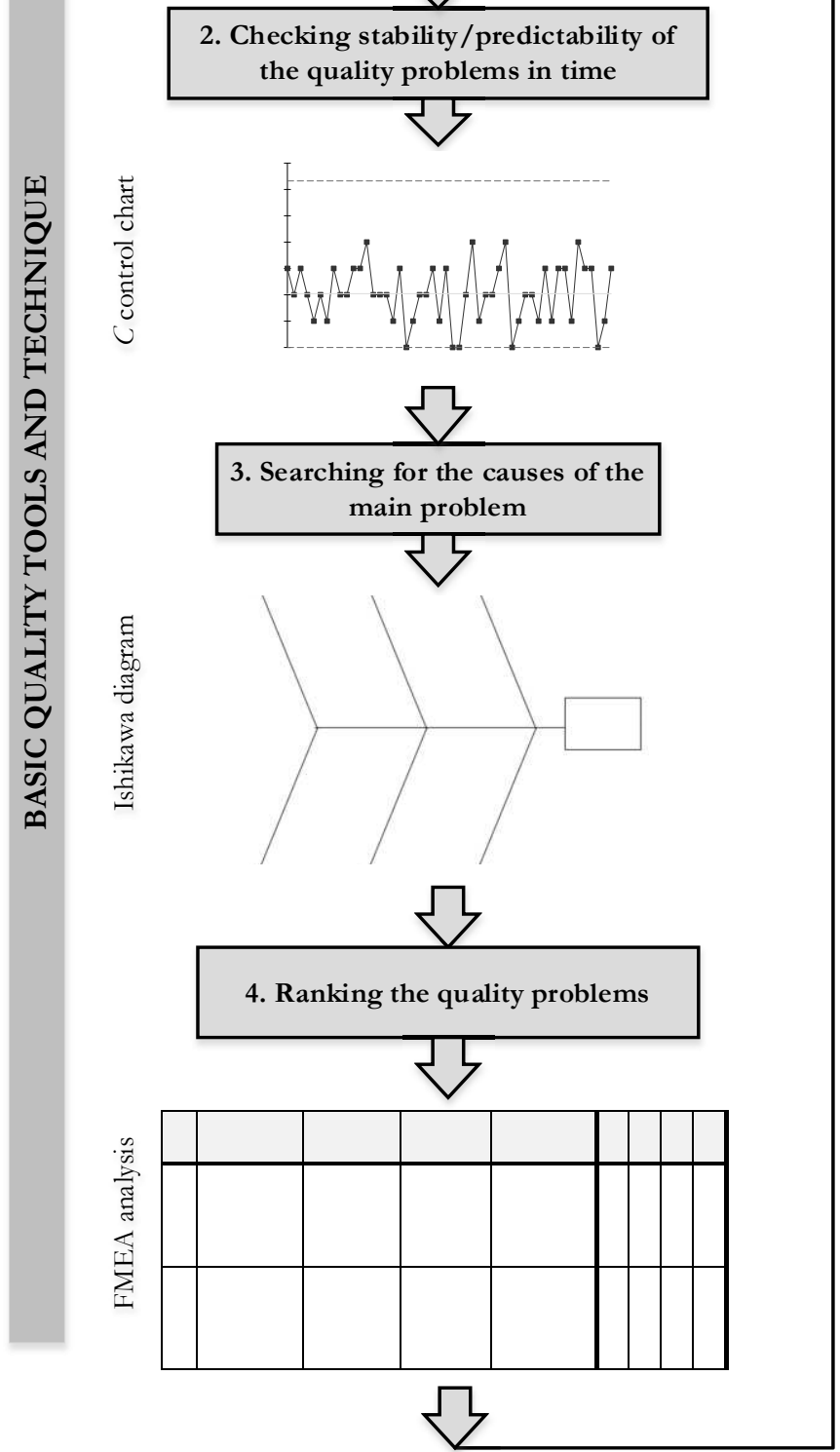

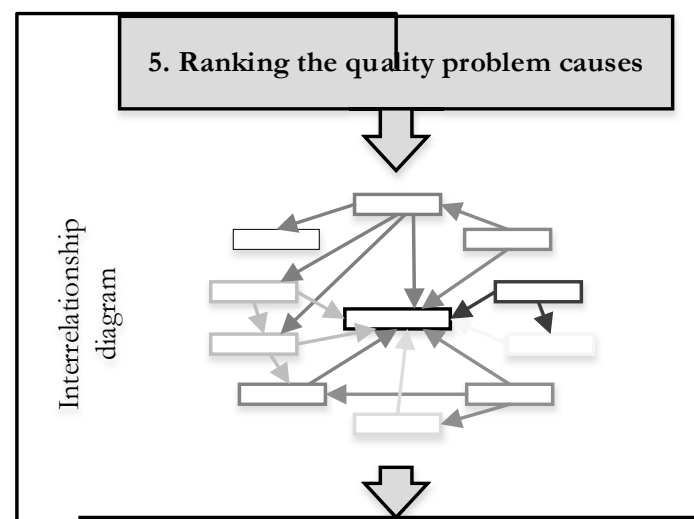

6. Identification of the relationship strength between quality problems and their causes

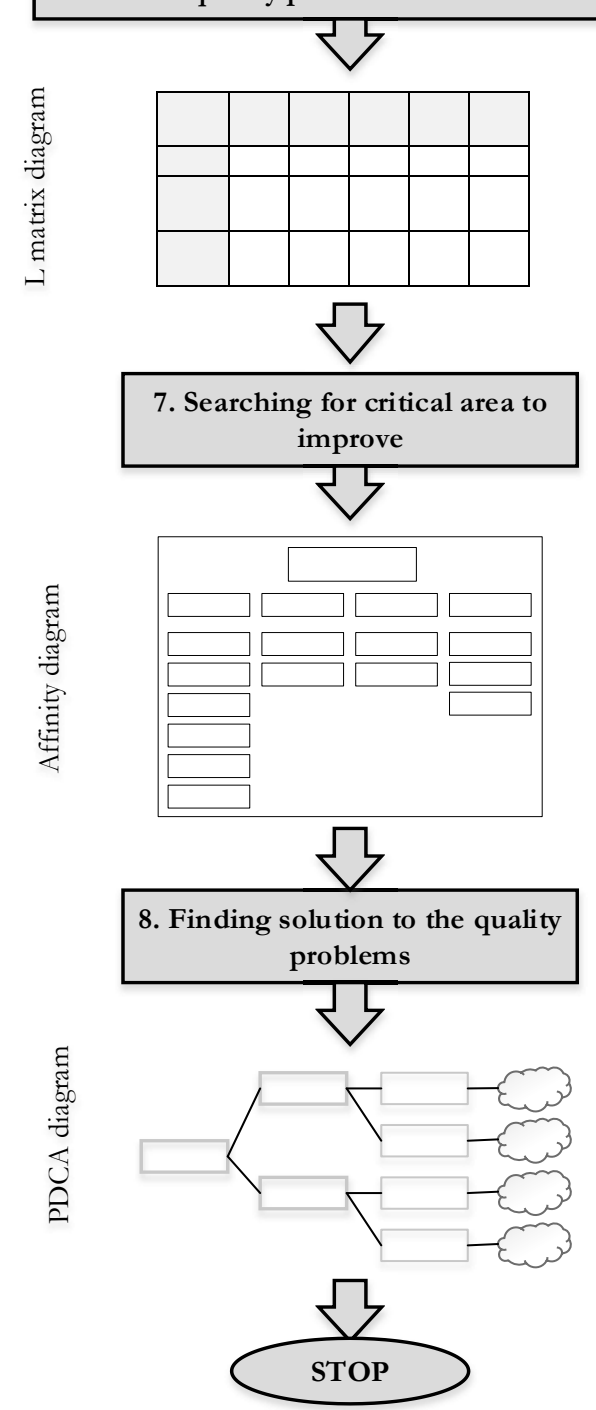

Fig. 1 Procedure of using selected quality tools and technique for the quality improvement

\section{Results}

Based on the research carried out on the defects of the painted surfaces of the product manufactured in the examined company, the following defects were found: W1 - thickness, W2 - underpainting, W3 - surface contamination, W4 - corrosion, W5 - fish eyes. Examples of occurred defects were presented in Fig. 2. 


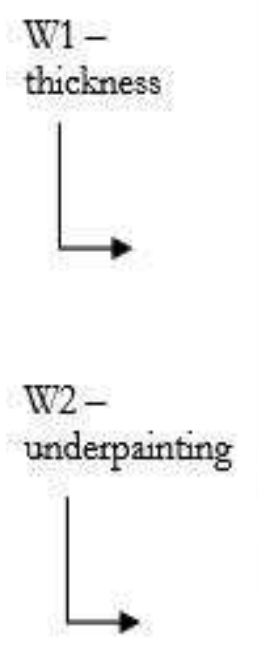

W3-surface
contamination

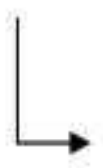

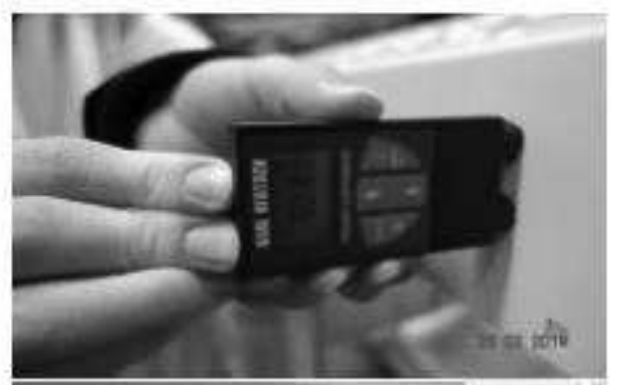

W4-

corrosion
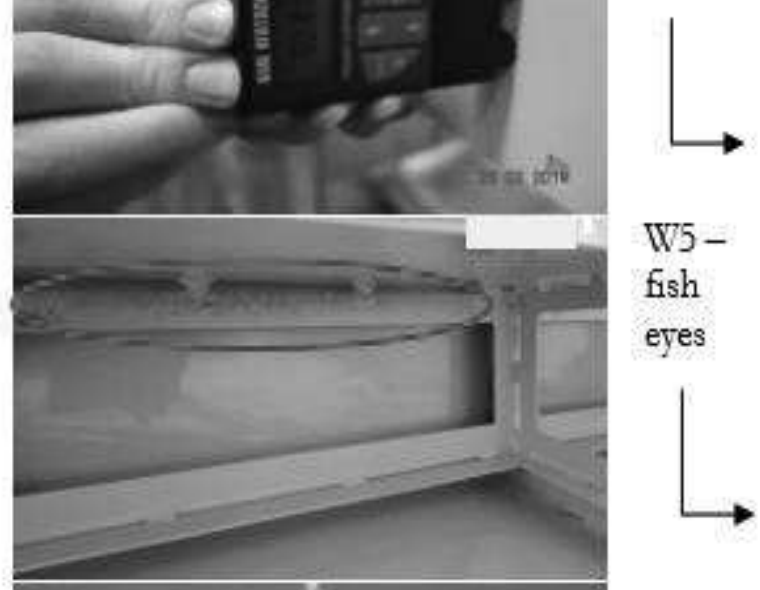

W5 -

fish

eyes

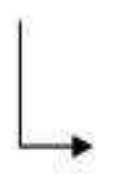

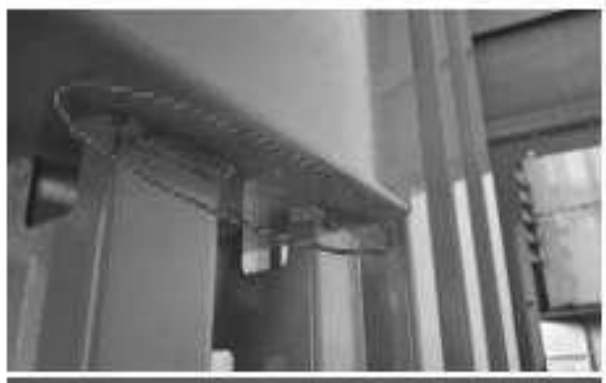

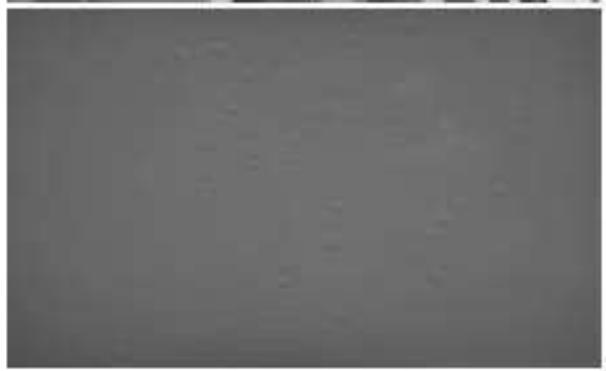

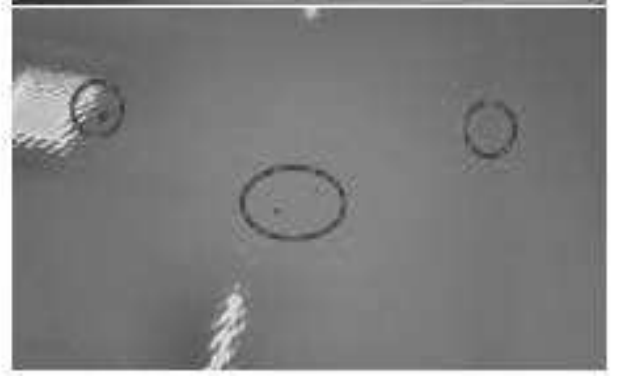

Fig. 2 Examples of occurred defects of the painted surfaces

The frequency of their occurrence was analyzed using the Pareto-Lorenz diagram. For this purpose, the defects were marked with symbols from W1 to W5 and ranked in order from the most frequently to the least frequently occured. The developed Pareto-Lorenz diagram is shown in Fig. 3.

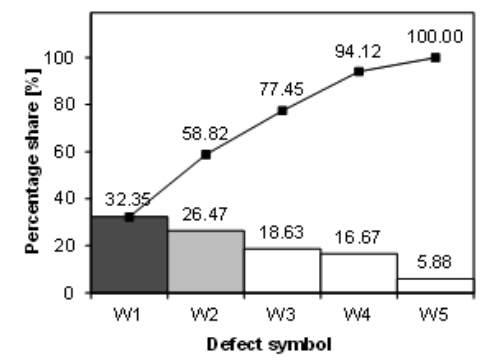

$$
\begin{aligned}
& \text { Legend: } \\
& \text { W1 - thickness } \\
& \text { W2 - underpainting } \\
& \text { W3 - surface contamination } \\
& \text { W4 - corrosion } \\
& \text { W5 - "fish eyes" }
\end{aligned}
$$

Fig. 3 Pareto-Lorenz diagram for the analysis of the frequency of occurrence of defects in painted surfaces

Because of the analysis, it was found that the most common defects of the varnish coating are the wrong thickness of the varnish layer and surface contamination. $40 \%$ of defects are responsible for $58.82 \%$ of all quality problems related to varnish coatings. It can be concluded that after eliminating defects marked as W1 (thickness) and W3 (surface contamination), the quality level should increase by $58.82 \%$.
The quality of the varnish coat of the tested product was inspected. As a measure of quality, the number of defects on the painted surface of the finished product leaving the coating department prior to the storage operations was used. The tests carried out were such that once a week the quality inspector checked the painted products (5 items) and counted the number of defects. 102 defects were found. The $c$ control chart was developed to assess the stability of the results (the number of defects) in the studied period. The developed $c$ control chart is presented in Fig. 4.

When analyzing the obtained control chart, it can be stated that in the examined period, none of the points exceeded the calculated control limits. Therefore, the process should be considered statistically controlled in terms of the number of defects, with random causes affecting it.

Using the Ishikawa diagram, an attempt was made to identify the causes that may affect the occurrence of paint defects. Because of brainstorming, six groups of causes have been identified that can most significantly affect the formation of defects in the manufactured product range. These groups are machines, materials, environment, method, employees, management. Fig. 5 shows the Ishikawa diagram for the mentioned groups of causes that may affect the formation of paint defects. 


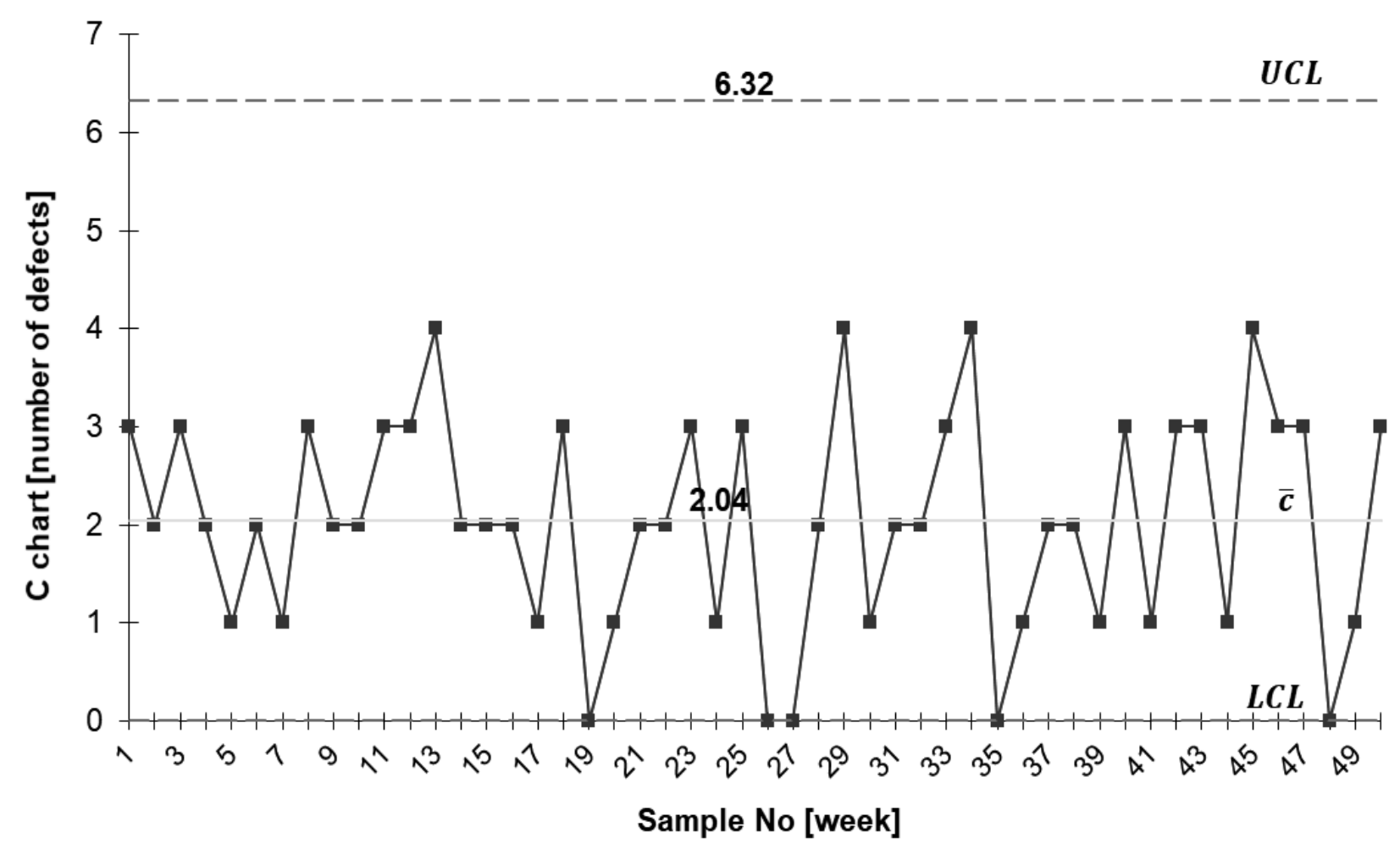

Fig. $4 C$ control chart (defects on the painted surface)

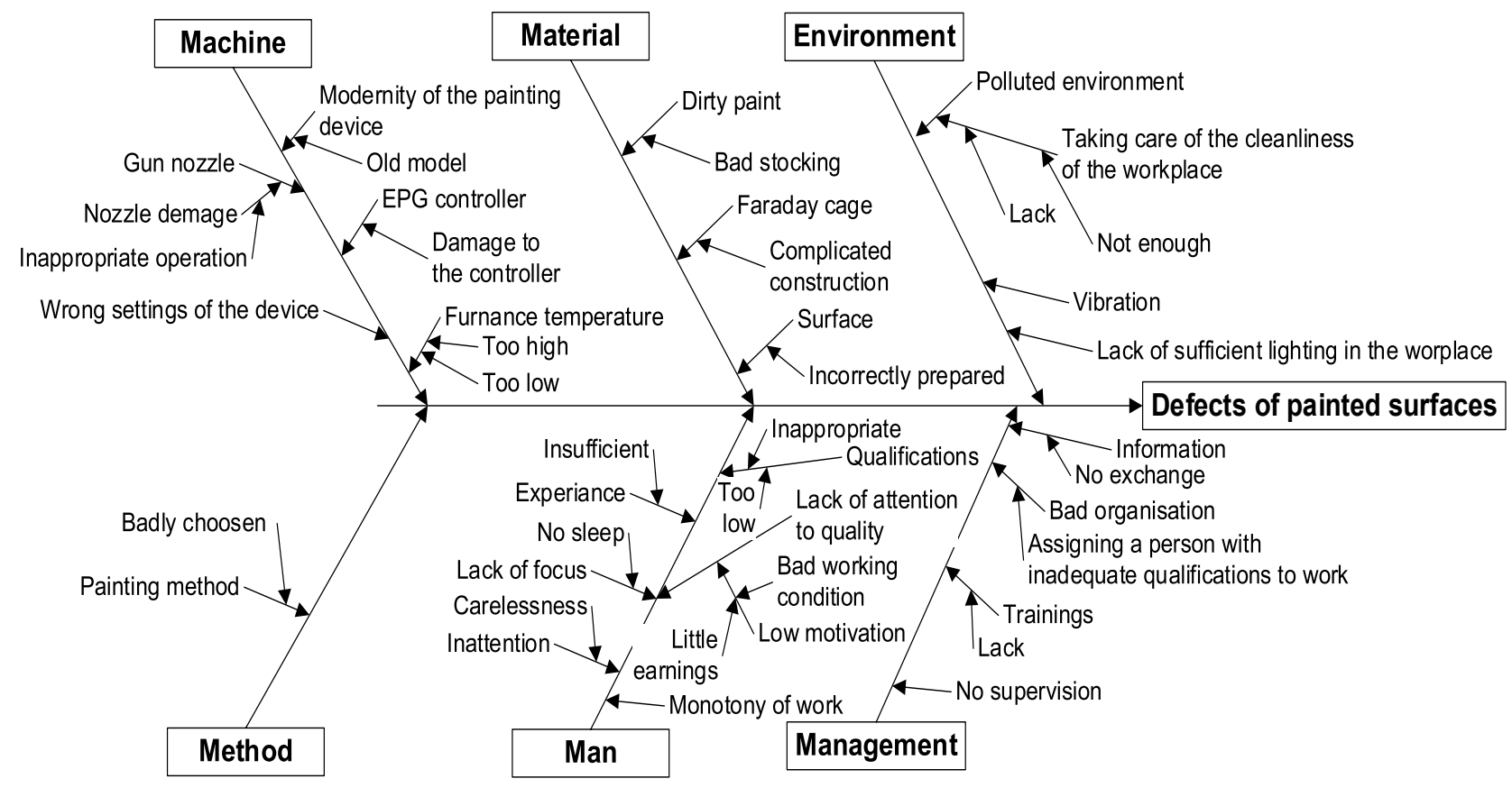

Fig. 5 Ishikawa diagram for the analysis of the causes of defects in painted surfaces

Because of the analysis, using the Ishikawa diagram, it was found that the groups of causes that most significantly affect the occurrence of surface defects of painted steel structures are, in order, employees, machines (technology and technological resources [36]), and management.

The analysis using the FMEA method for surface defects of painted steel structures in the tested product is presented in Table 2.

Based on the analysis of the FMEA sheet, it can be noticed that defects such as improper coating thickness (W1) and the presence of the so-called "Fish eyes" on the sidewall (W5) obtained the highest RPN value. This result indicates where the most urgent action should be taken to prevent these defects from occurring in the future. The management focus should 
be posed on employee changes: more training on painting technology, machine operation, and increased attention at every stage of the painting process.

The interrelationship diagram was used to analyze the causal and cause-effect relationships between all potential factors affecting the problem - paint defects. The results of the analysis are presented in Fig. 6.

Tab. 2 FME $A$ analysis for defects in painted surfaces

\begin{tabular}{|c|c|c|c|c|c|c|c|c|}
\hline No. & Defect & $\begin{array}{c}\text { The cause of } \\
\text { the defect }\end{array}$ & Effect of the defect & Remedial Actions & O & S & D & $\begin{array}{c}\text { P } \\
\text { N }\end{array}$ \\
\hline W1 & $\begin{array}{c}\text { Coating thickness in- } \\
\text { correct }\end{array}$ & $\begin{array}{c}\text { No experience } \\
\text { of the painter }\end{array}$ & $\begin{array}{c}\text { Nonconforming } \\
\text { product, needs to } \\
\text { be reapired }\end{array}$ & Staff training & 7 & 5 & 8280 \\
\hline W2 & $\begin{array}{c}\text { Unpainted surface of } \\
\text { the inner side of the } \\
\text { product }\end{array}$ & Faraday cage & $\begin{array}{c}\text { Unaesthetic appea- } \\
\text { rance of the pro- } \\
\text { duct }\end{array}$ & $\begin{array}{c}\text { Improving groun- } \\
\text { ding }\end{array}$ & 5 & 1 & 4 & 20 \\
\hline W3 & $\begin{array}{c}\text { Dirty surface of the } \\
\text { top wall }\end{array}$ & $\begin{array}{c}\text { Dirty painting } \\
\text { surroundings }\end{array}$ & $\begin{array}{c}\text { Unaesthetic appea- } \\
\text { rance of the pro- } \\
\text { duct }\end{array}$ & $\begin{array}{c}\text { Eliminate sources } \\
\text { of pollution }\end{array}$ & 6 & 3 & 3 & 54 \\
\hline W4 & $\begin{array}{c}\text { Corrosion on the in- } \\
\text { side of the beam }\end{array}$ & $\begin{array}{c}\text { Incorrect sur- } \\
\text { face preparation }\end{array}$ & $\begin{array}{c}\text { Required product } \\
\text { repair }\end{array}$ & $\begin{array}{c}\text { Surface inspection } \\
\text { before painting }\end{array}$ & 3 & 2 & 5 & 30 \\
\hline W5 & $\begin{array}{c}\text { The presence of the } \\
\text { so-called "fish eyes" } \\
\text { on the side wall }\end{array}$ & $\begin{array}{c}\text { Incorrect sur- } \\
\text { face preparation }\end{array}$ & $\begin{array}{c}\text { Unaesthetic appea- } \\
\text { rance of the pro- } \\
\text { duct }\end{array}$ & $\begin{array}{c}\text { Improving the qua- } \\
\text { lity of surface pre- } \\
\text { paration }\end{array}$ & 5 & 3 & 6 & 90 \\
\hline
\end{tabular}

where: O - Occurance [1-10], S - Serverity [1-10], D - Detection [1-10], RPN - Risk Priority Number [1-1000]

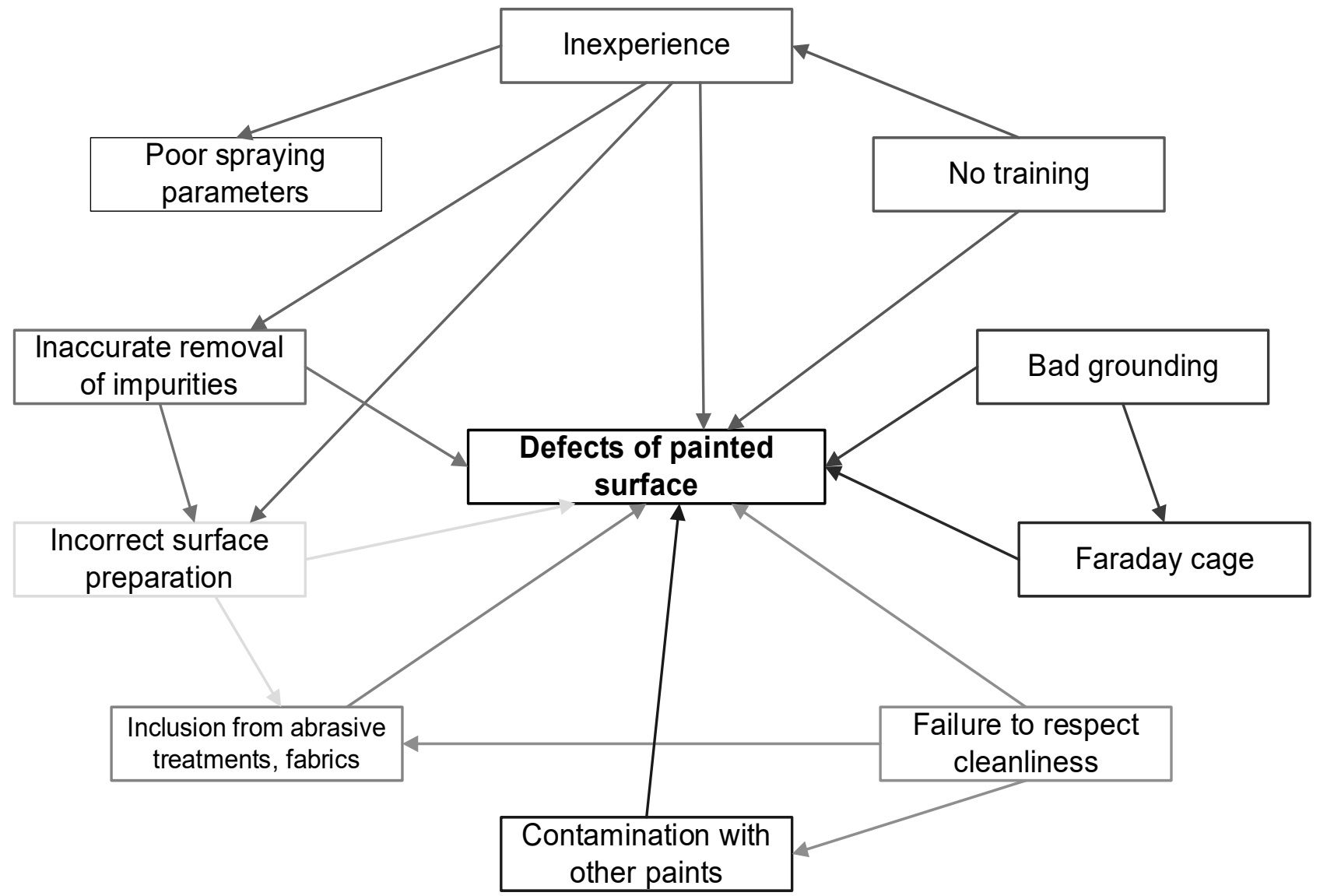

Fig. 6 The interrelationship diagram between the causes of defects in painted surfaces

The next step was to allocate the number of points on a scale of 1-3-9 (weak/moderate/strong) to determine the strength of the interrelationship between the factors. The obtained results of the analysis are presented in Table 3. 
Tab. 3 Determining the weight of factors in the interrelationship diagram

\begin{tabular}{|c|c|c|c|c|c|c|c|c|c|c|c|c|c|}
\hline $\begin{array}{c}\text { Factor } \\
\text { deno- } \\
\text { tation }\end{array}$ & Verbal description & 1. & 2. & 3. & 4. & 5. & 6. & 7. & 8. & 9. & 10. & $\begin{array}{c}\text { Impact } \\
\text { on the } \\
\text { problem }\end{array}$ & $\begin{array}{c}\text { Total } \\
\text { impact } \\
\text { (sum) }\end{array}$ \\
\hline 1. & No experience of the painter & $\mathrm{X}$ & 6 & & & 3 & & & & 9 & 9 & 9 & 36 \\
\hline 2. & No training & 6 & $\mathrm{X}$ & & & & & & & & & 3 & 9 \\
\hline 3. & Faraday cage & & & $\mathrm{X}$ & 3 & & & & & & & 3 & 6 \\
\hline 4. & Bad grounding & & & 3 & $\mathrm{X}$ & & & & & & & 3 & 6 \\
\hline 5. & Poor spraying parameters & 3 & & & & $\mathrm{X}$ & & & & & & 6 & 9 \\
\hline 6. & Failure to respect cleanliness & & & & & & $\mathrm{X}$ & 6 & 6 & & & 6 & 18 \\
\hline 7. & Contamination with other paints & & & & & & 6 & $\mathrm{X}$ & & & & 6 & 12 \\
\hline 8. & Inclusions from abrasive machining, fabrics & & & & & & 6 & & $\mathrm{X}$ & 6 & & 6 & 18 \\
\hline 9. & Incorrect surface preparation & 9 & & & & & & & 6 & $\mathrm{X}$ & 6 & 9 & 30 \\
\hline 10. & Inaccurate removal of impurities & 9 & & & & & & & & 6 & $\mathrm{X}$ & 9 & 24 \\
\hline
\end{tabular}

After counting the points, all the factors were ordered in descending order. Fig. 7 shows the ranking of the causes that should be eliminated firstly in order to get rid of the problem (from the most to the least important).

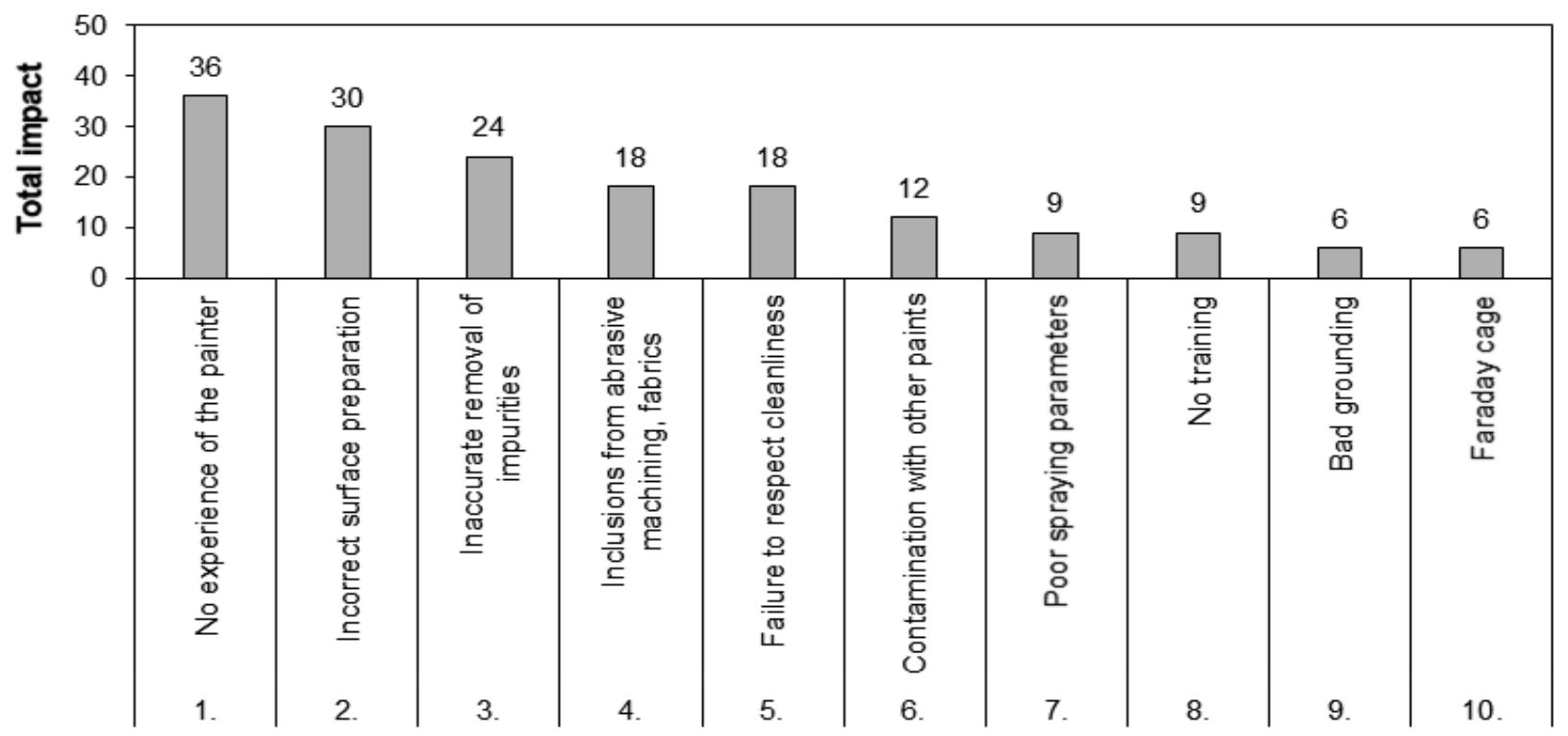

Significance of the factor

Fig. 7 Significance of factors in descending order

Based on the results from Fig. 7, it can be stated that the most important factor influencing the occurrence of defects in painted surfaces is the lack of experience of the varnisher and it is this problem that the company management should focus on, as it most influences other factors causing the problem.

Identification of the investigated causal factors was carried out in terms of their influence on the occurrence of paint coating defects. The analysis was performed in the form of a matrix diagram. The form of the "L" diagram was selected, and then the groups of factors were placed on the diagram (Table 4). The relationship between the factors of different groups was established using the following symbols: (-) weak relationship, (0) no relationship, $(+)$ strong relationship.
The analysis of the "L" matrix diagram shows that:

- surface defects of varnished coatings, such as contamination, corrosion, fish-eyes, are strongly dependent on the prior preparation of the surface,

- cleanliness of the environment strongly influences the formation of surface contamination,

- the painter's experience with varying strength affects every possible defect, in particular the aesthetics and thickness of the coating, which may be caused by the lack of training,

- bad grounding and Faraday cage strongly affect paint accuracy. 
Tab. 4 "L" matrix diagram - defects of painted surfaces

\begin{tabular}{|c|c|c|c|c|c|}
\hline & $\begin{array}{c}\text { Coating } \\
\text { thickness in- } \\
\text { correct }\end{array}$ & $\begin{array}{c}\text { Unpainted } \\
\text { surface }\end{array}$ & $\begin{array}{c}\text { Surface con- } \\
\text { tamination }\end{array}$ & Corrosion & Fish eyes \\
\hline 1 & 2 & 3 & 4 & 5 & 6 \\
\hline Incorrect surface preparation & & & + & + & + \\
\hline Inaccurate removal of impurities & & & + & + & 0 \\
\hline Failure to respect cleanliness & + & + & - & & 0 \\
\hline No experience of the painter & + & + & - & - & 0 \\
\hline $\begin{array}{c}\text { Inclusions from abrasive } \\
\text { machining, fabrics }\end{array}$ & & + & & & \\
\hline No training & + & + & & & \\
\hline Poor spraying parameters & 0 & + & & & \\
\hline Bad grounding & 0 & + & & & \\
\hline Faraday cage & & & & & \\
\hline
\end{tabular}

After the analysis with the use of the interrelationship diagram, it was concluded that the most serious factor influencing the formation of defects is the poor experience of employees, which was also confirmed by the analysis made with the use of a matrix diagram. During this analysis, it was also found that insufficient training for employees plays a key role in the formation of defects, and it is from this aspect that the company management should start its activities in order to improve the quality of the product offered.

In order to find a solution to the examined problem related to the defects of painted surfaces, a team of five employees, after being acquainted with the general problem, created a list of ideas about the causes of this problem (using the brainstorming technique). The affinity diagram (Fig. 8) was used to group the causes into common thematic categories.

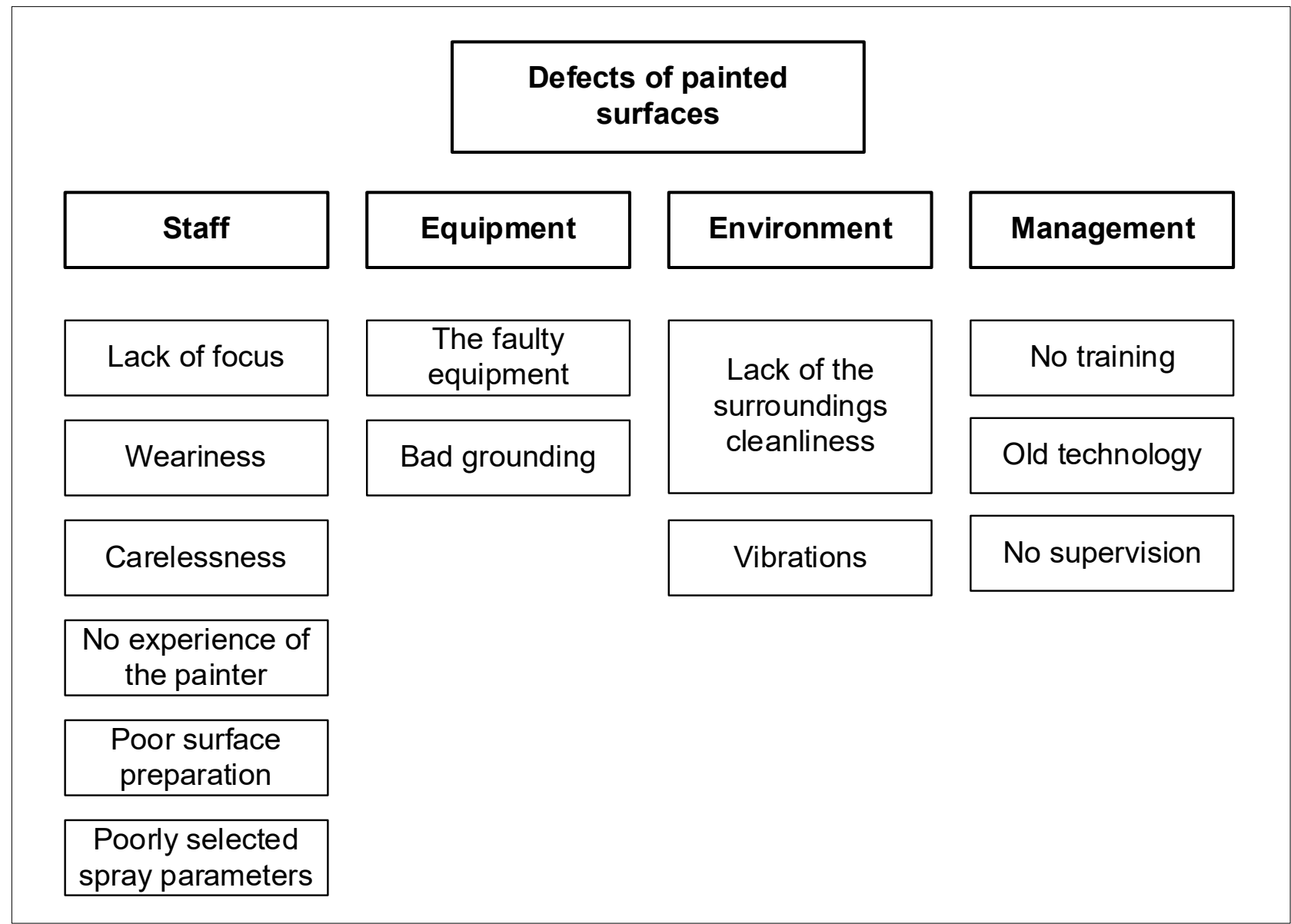

Fig. $\boldsymbol{8}$ Affinity diagram after grouping the causes of the problem - defects in painted surfaces - into common thematic categories 
The analysis carried out with the use of the affinity diagram showed that the highest number of reasons for the occurrence of the defects belongs to the staff category and activities should be focused on this category to solve the analysed quality problem - defects of painted structures. The rest of the causes problems were equally divided among the other 3 categories, which shows that they have a similar effect on the formation of the defects.

A team of five people was presented with the goal: to paint the element correctly. Then, important issues for its implementation were dictated and potential di- fficulties were analyzed. All problems are classified according to their priority, probability of occurrence, difficulties in prevention and the associated risk. The next step was to plan countermeasures for the problems that were considered a priority and to draw up a PDPC diagram (Fig. 8). The conducted analysis was aimed at determining the activities allowing preventing the occurrence of the most common varnish defects on the tested product. Based on the revealed threats, a list of proposed actions and remedial measures has been prepared, which were presented in the Figure 9 as "clouds".

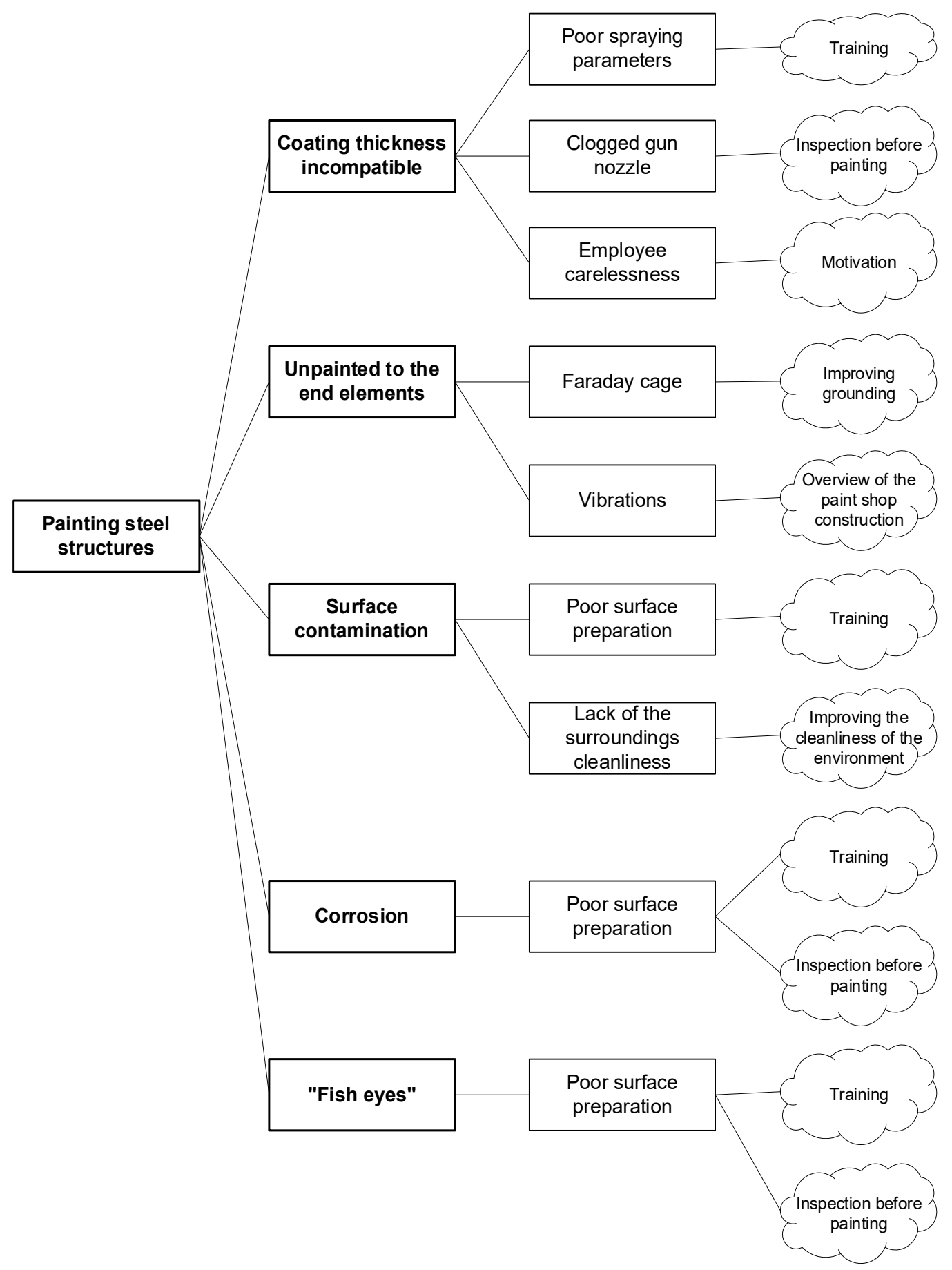

Fig. 9 PDPC diagram for the presentation of countermeasures limiting the chance of occurrence of defects in painted steel structures 
After the analysis with the use of the interrelationship diagram, affinity diagram, and the PDPC diagram, it is concluded that the largest group of causes of defects in painted surfaces were those created by the staff (blue-collar workers). The PDPC analysis showed activities that should be carried out by the company management in order to eliminate the occurrence of the defects, and thus improve the quality of the product offered. The company management should focus on aspects, such as employee training, increased motivation, periodic inspections of machines, equipment, and paint shop structures, care for the cleanliness of the workplace, improvement of quality control at the stage of preparation for painting, improvement of grounding.

\section{Conclusion}

The aim of this article was to analyze the surface defects of painted steel structures on the example of a selected element of the tested company with the use of selected quality tools and techniques. In the article was analyzed the causes of surface defects, their characteristics, and was proposed methods of prevention. This was a particularly important issue for the company management because defects on the painted surface led to the need for reworks or repairs and generated costs related to "not doing work right the first time" or if the product reaches the customer, generated costs related to complaints.

With the use of selected quality tools and techniques, analyzes were carried out on the analyzed problem - defects of painted surfaces. Pareto-Lorenz's analysis proved that the most common defects of painted surfaces turned out to be inadequate thickness and surface contamination. The cause of these defects was largely due to the experience of employees, which was also confirmed by the analyzes carried out using the FMEA method and the PDPC diagram, and in the case of surface contamination, the cleanliness of the surroundings (environment) played an important role. The analysis of the causal factors using the Ishikawa diagram showed that most of them were related to the worker, machine, and management. The affinity diagram also confirmed the fact of the special contribution of the human factor in the formation of defects. The conducted analyzes showed that the most important factor influencing the occurrence of defects in painted surfaces was the lack of experience of the varnisher, which was confirmed by the results of the interrelationship diagram analysis and the matrix diagram. The insufficient experience of the employee was an extremely important factor, as it influenced the formation of other causes generating defects. The training was the most frequent proposed method of prevention in this aim. Conducting pieces of training could increase the employees' experience in the proper use of machines and devices, preparation of the element before painting, and proper painting.

Summing up, in order to avoid defects in the surfaces of painted steel structures, the examined company should increase the number of training courses for paint shop employees and also pay special attention to the effectiveness and quantity of quality control, especially visual [37]. The effectiveness of the self-control process during the painting process should also be increased so that the causal factors influencing the formation of defects are identified at the earliest stage. An important activity in order to prevent defects is also periodic inspection, maintenance of machines and devices used throughout the painting process, taking care of the cleanliness of the environment in order to eliminate sources of possible contamination, and periodic inspection of the paint shop structure to minimize the occurring vibrations. It has been shown that the preparation of the surface before painting is a very important aspect, as it affects the formation of 3 out of 5 defects in the painted steel structures.

A factor that should improve surface preparation is increased inspection and trainings in this topic. To strengthen the effect of changes, it is also necessary to implement Lean tools [38] that will eliminate waste from the painting process and use Six Sigma cycles (DMADV and DMAIC) [39] that will eliminate errors in product and process and reduce the overall costs of poor quality. The culture of the organization should also be changed. It is important to create in the company an atmosphere of mutual respect and equal treatment of all employees on the part of their supervisor. This may contribute to a better atmosphere in the described company and an increase in employee satisfaction with their work. Generally, it is important for analyzed company to move towards sustainable development [40].

The practical application of quality tools presented in the article was aimed at showing their benefit, simplicity, and strength in the quality improvement process. The set of qualitative tools used during research was an important element in the analysis and search for solutions to the analysed quality problems. The management of the analyzed company uses the potential of quality tools with greater certainty to identify, analyze, evaluate and solve the detected quality problems, which translates into cost reduction and greater satisfaction of its internal and external customers.

\section{References}

[1] ISO 9000:2015. Quality management systems - Fundamentals and vocabulary.

[2] GYGI, C., GUSTAFSON, T., WILLIAMS, B. (2006). Six Sigma Workbook for Dummies. Hoboken, NJ (USA): Wiley Publishing, Inc. ISBN10: 0-470-04519-1. 
[3] TAGUE, N. R. (2005). The Quality Toolbox (2nd ed.). Milwaukee, Wisconsin: ASQ Quality Press. ISBN 978-1-62198-045-2.

[4] ULEWICZ, R. (2014). Practical Application of Quality Tools in the Cast Iron Foundry. In: Manufacturing Technology, Vol. 14, No. 1, pp. $104-$ 111. ISSN 1213-2489.

[5] FONSECA, L., LIMA, V., SILVA, M. (2015). Utilization of quality tools: Does sector and size matter? In: International Journal for Quality Research, Vol. 9, No. 4, pp. 605 - 620. ISSN 18006450.

[6] RAKHMANIAR, M., RAHMANIA, I.M., SETYANINGSIH, S., BASRI, M.H. (2012). Application of Quality Tools and Techniques in Hospital: Case Study in Bandung Indonesia. In: 3rd International Research Symposium in Service Management, July 3-7, 2012, Beijing.

[7] HADIMAN, N., HUMIRAS, H. P. (2017). Aplication of quality control tools to reducing defect product in a surfactant and chemicals industry. In: International Journal of Modern Trends in Engineering and Research (IJMTER), Vol. 04, Iss. 12, pp. 261 - 271. e-ISSN 2349-9745.

[8] SANNY, L., AMALIA, R. (2015). Quality improvement strategy to defect reduction with seven tools method: Case in food field company in Indonesia. In: International Business $\mathrm{Ma}$ nagement, No. 9, pp. 445 - 451. ISSN 1993-5250.

[9] MEMON, I.A., JAMALI, Q.B., JAMALI, A.S., ABBASI, M., JAMALI, N., JAMALI, Z. (2019). Defect Reduction with the Use of Seven Quality Control Tools for Productivity Improvement at an Automobile Company. In: Engineering, Technology \& Applied Science Research, Vol. 9 , No. 2, pp. 4044 - 4047. eISSN 1792-8036.

[10] LIANG, K. (2010). Aspects of Quality Tools on Total Quality Management. In: Modern Applied Science, Vol. 4, No. 9, pp. 66 - 74. e-ISSN 1913-1852.

[11] SOUSA, S., RODRIGUES, N., NUNES, E. (2017). Application of SPC and quality tools for process improvement. In: Procedia Manufacturing, Vol. 11, pp. 1215 - 1222. ISSN 2351-9789.

[12] TARÍ, J., SABATER, V. (2004). Quality tools and techniques: Are they necessary for quality management? In: International Journal of Production Economics, Vol. 92, No. 3, pp. 267 - 280. ISSN: 0925-5273.

[13] MCQUATER, R.E., SCURR, C.H., DALE, B.G., HILLMAN, P.G. (1995). Using quality tools and techniques successfully. In: The TQM
Magazine, Vol. 7, No. 6, pp. 37 - 42. ISSN 0954478X.

[14] VIJAYARANGAN, J., SAMY, M. A., BHARATHIRAJA, G., RAGUL, G. \& SHERIFF F. M. (2017). Implementation of seven tools of quality in educational arena: A case study. In: International Journal of Mechanical Engineering and Technology (IJMET), Vol. 8, Iss. 8, pp. 882 - 891. e-ISSN 0976-6359.

[15] PAVLETIC, D., SOKOVIC, M., PALISKA, G. (2008). Practical Application of Quality Tools. In: International Journal for Quality Research, Vol. 2, No. 3, pp. 199 - 205. e-ISSN: 18007473.

[16] PACANA, A., CZERWIŃSKA, K. (2020). Improving the quality level in the automotive industry. In: Production Engineering Archives, Vol. 26, Iss. 4, pp. 162 - 166. e-ISSN 2353-7779.

[17] BAMFORD, D. R., GREATBANKS, R. W. (2005). The use of quality management tools and techniques: a study of application in everyday situations. In: International Journal of Quality \& Reliability Management, Vol. 22, No. 4, pp. 376 - 392. ISSN 0265-671X.

[18] DIAS, S., SARAIVA, P.M. (2004). Use basic quality tools to manage your processes. In: Quality Progress, Vol. 37, pp. 47 - 53. ISSN 0033524X.

[19] ABDEL-HAMID, M., ABDELHALEEM, $\mathrm{H}$. (2019). Improving the Construction Industry Quality Using the Seven Basic Quality Control Tools. In: Journal of Minerals and Materials Characterization and Engineerin, Vol. 7, No. 6, pp. 412 420. e-ISSN 2327-4085.

[20] ANDRÁSSYOVÁ, Z., ŽARNOVSKÝ, J., ÁLLÓ, Š., HRUBEC, J. (2013). Seven New Quality Management Tools. In: Advanced Materials Research, Vol. 801, pp. 25 - 33. ISSN: $1662-$ 8985.

[21] MIZUNO, S. (1988). Management for Quality Improvement: The 7 New QC Tools. Woodland Hills, CA (USA): Productivity Pr. Inc. ISBN 10: 0915299291.

[22] NAYATANI, Y., EIGA, T., FUTAMI, R. (2006). The seven QC tools: New tools for a new era. In: Environmental Quality Management, Vol. 4, No. 1, pp. 101 - 109. ISSN 15206483.

[23] DAMAYANTI, R., SUBAGYO, B., WIJAYA, A., HARTONO, B. (2019). Seven Management and Planning Tools in Megaproject Management: A Literature Review. IOP Conference Series: Materials Science and Engineering, 598, 012014. 
[24] SIWIEC, D., PACANA, A. (2021). Method of improve the level of product quality. In: Production Engineering Archives, Vol. 27, Iss. 1, pp. 1 7. e-ISSN 2353-7779.

[25] HAGEMEYER, C., GERSHENSON, J.K. JOHNSON, D.M. (2006). Classification and application of problem solving quality tools: A manufacturing case study. In: The TQM Magazine, Vol. 18, No. 5, pp. 455 - 483. ISSN $0954-$ 478X.

[26] KARDAS, E. (2017). The Analysis of Non-Conformances of Products in Plate Mill Using Selected Quality Tools. In: 26th International Conference on Metallurgy and Materials (METAL 2017), Tanger, Ostrava. ISBN 978-80-87294-79-6.

[27] KNOP, K. (2018). Statistical control of the production process of rolled products. In: Production Engineering Archives, Vol. 20, pp. 26 - 31. ISSN 2353-5156.

[28] KNOP, K. (2021). Managing and Improving the Drilling Process of Woodwork Furniture with the Use of SPC Tools. In: Manufacturing Technology, Vol. 21, Iss. 4, pp. . e-ISSN 27879402.

[29] GODINA, R., MATIAS, J., AZEVEDO, S. (2016). Quality improvement with Statistical Process Control in the automotive industry. In: International Journal of Industrial Engineering and Management, Vol. 7, No. 1, pp. 1 - 8. ISSN 2217 2661.

[30] MONTGOMERY, D.C. (2012). Statistical Quality Control, 7th Edition. Hoboken, NJ (USA): Wiley. ISBN: 978-1-118-14681-1.

[31] DZIUBA, SZ. T., INAGALDI, M., KOZINA, A., HERNES, M. (2021). Using the FMEA Method as a Response to a Customer Complaint: a Case Study. In: Revista Gestao \& Tecnologia-Journal of Management and Technology, Vol. 21, No. 1, pp. 73 - 88. e-ISSN: 2177-6652.

[32] KAPUSTKA, K., ZIEGMANN, G., KLIMECKA-TATAR, D., SARA NAKONCZY, S. (2020). Process management and technological challenges in the aspect of pernament magnets recycling - the second life of neodymium magnets. In: Manufacturing Technology, Vol. 20, Iss. 5, pp. 617 - 624. e-ISSN 2787-9402.
[33] KRYNKE, M., MIELCZAREK, K., KIRILIUK, O. (2021). Cost Optimization and Risk Minimization during Teamwork Organization. In: Management Systems in Production Engineering, Vol. 29, Iss. 2, pp. 145 - 150. e-ISSN 2450-5781.

[34] CZAJKOWSKA, A., INGADLI, M. (2021). Application of Servqual and Servperf methods to assess the quality of teaching services - comparative analysis. In: Manufacturing Technology, Vol. 21, Iss. 3, pp. 294 - 305. e-ISSN 27879402.

[35] INGALDI, M. (2021). Assessment of the Service Provision Process as a Business Process Management Tool. In: Polish Journal of Management Studies, Vol. 23, No. 1, pp. $204-223$. ISSN 20817452.

[36] KNOP, K., ULEWICZ, R. (2019). Assessment of technology, technological resources and quality in the manufacturing of timber products. In: 12th WoodEMA Annual International Scientific Conference on Digitalisation and Circular Economy: Forestry and Forestry Based Industry Implications, pp. 251 - 256. USB \& WoodEMA, Sofia, Bulgaria. ISBN 978-954-397-042-1.

[37] KNOP, K. (2020). Indicating and Analysis the Interrelation Between Terms - Visual: Management, Control, Inspection and Testing, In: Production Engineering Arcbives, Vol. 26, Iss. 3, pp. 110 - 120. e-ISSN 2353-7779.

[38] ULEWICZ, R., KLESZCZ, D., ULEWICZ, M. (2021). Implementation of Lean Instruments in Ceramics Industries, In: Management Systems in Production Engineering, Vol. 29, Iss. 2, pp. 203 - 207. e-ISSN 2450-5781.

[39] PENDOKHARE, D. G., QUAZI, T., KULKARNI, P. S. (2015). Redesign and Manufacturing by using DMADV Method. In: International Journal of Research in Engineering and Technology, Vol. 4, No. 2, pp. 144 - 149. eISSN: 2319-1163.

[40] KLIMECKA-TATAR, D., INGALDI, M., OBRECHT, M. (2021). Sustainable Development in Logistic - a Strategy for Management in Terms of Green Transport. In: Management Systems in Production Engineering, Vol. 29, Iss. 2, pp. 91 - 96. e-ISSN 2450-5781. 